\title{
Why is Heart Rarely Affected by Cancer?
}

\section{Sisir Nandi* and Pragya Chaudhary}

Global Institute of Pharmaceutical Education and Research, Affiliated to Uttarakhand Technical University, Kashipur-244713, India

\section{Editorial}

Cancer is a malignant neoplasm defined as an abnormal growth and division of cells. Molecular mechanisms of cancer predicted that there are two broad categories of genes such as proto-oncogenes and tumor suppressor genes control mitotic cell division. Tumor suppressor genes inhibit cell division, survival, or other properties of cancer cells. Oncogenes are the mutations of normal host genes which are protooncogene. Proto-oncogenes are good genes that normally control the essential cell functions such as cell proliferation and differentiation through signal transduction. Abnormal signal transduction can lead to cancer which engulfs the brain, blood, lymph nodes, lungs, bone, and every other bodily organ, part, or system. But why is heart rarely affected by the cancer? This answer is much more silent yet and literature on heart cancer is quite limited. So it is very crucial topic for the genomic scientist and pharmacologist to explore the reason behind this. Primary cardiac tumor was scarce whereas malignant heart tumors also known as angiosarcoma or cardiac sarcoma are extremely rare. A sarcoma is a type of tumor that originates in the soft tissues of the body. A type of rhabdomyosarcoma occurs in the cardiac muscle tissues (Figure 1).

McAllister et al. [1] analyzed the data of 22 large autopsy series and primary cardiac tumors were reported as an approximately $0.02 \%$. Habertheuer et al. reported a number of 200 primary cardiac tumors in 1 million autopsies [2]. An incidence is estimated at less than 0.05 percent, based on a study of more than 12,487 autopsies performed in Hong Kong, which identified only seven cases of any kind of primary cardiac tumor [3]. At Mayo Clinic, on average only one case of heart cancer is seen each year. In a study conducted in the Hospital of the Medical University of Vienna 113 primary cardiac tumor cases were identified in a time period of 15 years with 11 being malignant. The

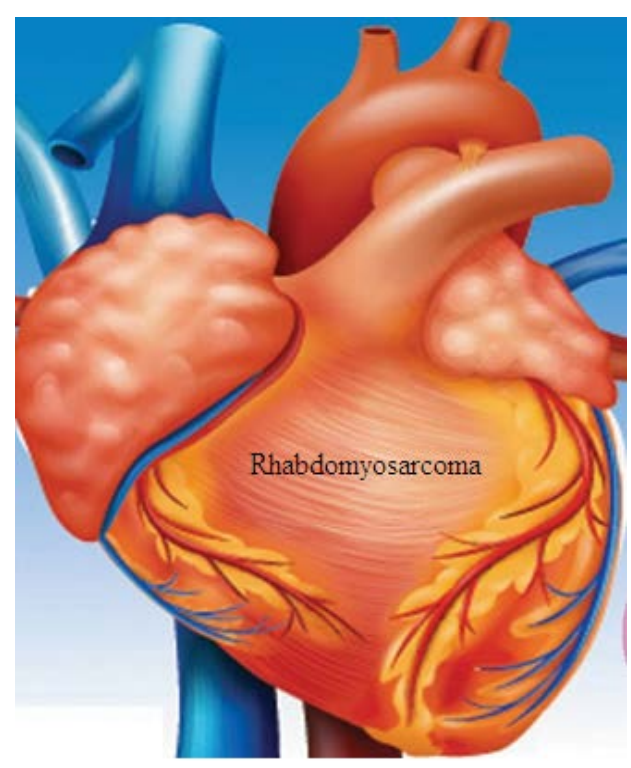

Figure 1: Rhabdomyosarcoma in heart. mean survival in the latter group of patients was found to be $26.2 \pm 9.8$ months [4].

Dr. Mitchell Gaynor, Clinical Assistant Professor at Weill Cornell Medical College, wrote "There's not a lot of fatty tissue [in the heart]," Gaynor said. Even more, "the heart's enclosed in a membrane," he explained. Known as the pericardium, this fluid-filled sac may itself become engulfed by cancer, with tumors metastasizing to the outside of it, but still it does its job of protecting our precious hearts [5].

The reason behind angiosarcoma is unknown yet. The hypothesis is that tumor suppressor gene may responsible for inhibition/antagonize/ prevention of abnormal cell division in CVS. The human heart is believed to grow by enlargement but not proliferation of cardiomyocytes (heart muscle cells) during postnatal development. But it is not true. Mollova and colleagues have shown that cardiomyocyte proliferation contributes to heart growth in young humans till 20 years of old [6]. Therefore it is postulated that the heart may contain some specific gene which is not expressed or stimulated abnormally in response to any factors such as mutagen. This postulation is in agreement with the echocardiographic study of Akt1 gene deficient mice model which revealed that deletion of Akt1 caused substantial activation of p38MAPK leads to abnormal cardiomyocyte proliferation [7]. Therefore, further genomic study of heart may focus some inputs to analyses the presence of specific gene which prevent abnormal proliferation of cardiac cells.

\section{References}

1. McAllister HA, Hall RJ, Cooley DA (1999) Tumors of the heart and pericardium. Curr Probl Cardiol 24: 57-116.

2. Habertheuer A, Ehrlich M, Wiedemann D, Mora B, Rath C, et al. (2014) A rare case of primary cardiac b cell lymphoma. J Cardiothorac Surg 9: 14.

3. Moynihan TJ (2015) Heart cancer: Is there such a thing? MayoClinic.

4. Habertheuer A, Laufer G, Wiedemann D, Andreas M, Ehrlich M, et al. (2015) Primary cardiac tumors on the verge of oblivion: a European experience over 15 years. J Cardiothorac Surg 10: 56.

5. Gaynor ML (2015) The Gene Therapy Plan: Taking Control of Your Genetic Destiny with Diet and Lifestyle.

6. Mollova M, Bersell K, Walsh S, Savla J, Das LT, et al. (2013) Cardiomyocyte proliferation contributes to heart growth in young humans. Proc Natl Acad Sci USA 110: 1446-1451.

7. Chang Z, Zhang Q, Feng Q, Xu J, Teng T, et al. (2010) Deletion of Akt1 causes heart defects and abnormal cardiomyocyte proliferation. Dev Biol 347: 384-391.

*Corresponding author: Sisir Nandi, Division of Pharmaceutical Chemistry, Global Institute of Pharmaceutical Education and Research, Uttarakhand Technical University, Kashipur-244713, India, Tel: +91 7500458478; E-mail: sisir.iicb@gmail.com

Received January 24, 2017; Accepted January 26, 2017; Published February 02, 2017

Citation: Nandi S, Chaudhary P (2017) Why is Heart Rarely Affected by Cancer? J Bioanal Biomed 9: e148. doi: 10.4172/1948-593X.1000e148

Copyright: ( 2017 Nandi S, et al. This is an open-access article distributed under the terms of the Creative Commons Attribution License, which permits unrestricted use, distribution, and reproduction in any medium, provided the original author and source are credited. 